\title{
Synthesis and Evaluation of Guanidine-Containing Schiff Base Copper(II), Zinc(II), and Iron(III) Chelates as Trypsin Inhibitors
}

\author{
Eiko Toyota, Haruo Sekizaki, Kunihiko Itoh, and Kazutaka Tanizawa* \\ Faculty of Pharmaceutical Sciences, Health Sciences University of Hokkaido; Ishikari-Tobetsu, Hokkaido 061-0293, \\ Japan. Received January 9, 2003; accepted March 14, 2003
}

\begin{abstract}
3-Formyl-4-hydroxyphenylguanidine hydrochloride and its Schiff base copper(II), zinc(II), and iron(III) chelates were synthesized and their inhibitory activity against bovine $\beta$-trypsin were determined. Syntheses of Schiff base metal chelates were carried out from 3-formyl-4-hydroxyphenylguanidine, various L-amino acids, and divalent metal acetate. Their structures were established on the basis of spectroscopic evidence and elemental analysis. The inhibitory activity of these chelates against bovine $\beta$-trypsin was determined. The guanidine-containing copper(II) and zinc(II) chelates behaved as potent competitive inhibitors of trypsin. However, similar inhibitory activity was not observed for guanidine-containing iron(III) chelates. The inhibition constants $\left(K_{\mathrm{i}}\right.$ values, $\mathrm{ca} . \mathbf{1 0}^{-5} \mathrm{M}$ ) of guanidine-containing Schiff base copper(II) and zinc(II) chelates were slightly lower than those $\left(\right.$ ca. $\left.10^{-6} \mathrm{M}\right)$ of the corresponding amidine-containing Schiff base chelates with regard to bovine trypsin.
\end{abstract}

Key words guanidinium group; Schiff base; metal chelate; trypsin; inhibition constant

Studies on trypsin-specific compounds are useful for the design of clinically useful compounds, since a variety of physiologically important enzymes (e.g., enzymes of the blood-clotting cascade, kallikrein and urokinase) have trypsin-like specificity. Several benzamidine and phenylguanidine derivatives have been reported to be potent inhibitors of trypsin-like enzymes. ${ }^{1-12)} \mathrm{X}$-ray crystallographic studies of trypsin complex prepared with benzamidine derivatives indicated that inhibition arises primarily from the interaction between the cationic amidinium group of the inhibitor and the anionic carboxyl group of Asp189 in the S1 site of trypsin. ${ }^{13-16)}$ The guanidinium group of guanidinebased inhibitors had also electrostatically favorable interaction with the carboxyl group of Asp189. ${ }^{17-19)}$

It is well known that metal ions serve to enhance the structural stability of proteins or take part in the catalytic processes of enzymes. ${ }^{20)}$ Transition metals such as copper(II), zinc(II), and nickel(II) also inhibit trypsin activity by direct binding to the imidazole nitrogen of histidine residues. ${ }^{16,21,22)}$ Thus we have been interested in the Schiff base metal chelates carrying the amidinium group as trypsin inhibitors. We have previously reported that the Schiff base copper(II) and iron(III) chelates prepared from various $\alpha$ amino acids, metal ions, and 4-formyl-3-hydroxybenzamidine or 3-formyl-4-hydroxybenzamidine are potent inhibitors of bovine $\beta$-trypsin. ${ }^{23,24)}$ To elucidate further the structureactivity relationships in this novel series of inhibitors, we have studied the crystal structures of trypsin complex with amidine-containing Schiff base copper(II) or iron(III) chelate. ${ }^{25)}$ It became clear that the difference in the positioning of the amidinium group on the benzene ring has dramatic effects on the binding modes. In the Schiff base copper(II) chelates derived from 4-formyl-3-hydroxybenzamidine (para position), the amino acid moiety as a part of the Schiff base is situated near the active site of trypsin, whereas the copper(II) ion is positioned in the region away from the active site residues of trypsin. In contrast, in the Schiff base copper(II) chelates derived from 3-formyl-4-hydroxybenzamidine (meta position), the copper(II) ion is directly coordinated to the imidazole nitrogen of His57 (bond distance, $3.1 \AA$ ), and the phenolic oxy- gen atom of the Schiff base forms a hydrogen bond with Ser195. This result suggests new avenues for the design of even more potent inhibitors based on combining a metal chelate motif with a cationic S1 recognition element. For example, guanidine-containing Schiff base metal chelates may show higher affinity for trypsin than amidine-containing chelates, because the distance between the positive charge of the guanidinium group and the metal ion is approximately $1.3 \AA$ longer than that of the amidine-containing Schiff base metal chelate. In the meta-substituted guanidine-based inhibitors therefore, the increased chain length of the inhibitor may allow tighter coordination between the metal ion and the imidazole nitrogen of His57 of trypsin than amidine-based inhibitors. Furthermore, the guanidinium group has three nitrogen atoms, which may form hydrogen bonds with S1 site residues of trypsin or solvent molecule, and then the interaction between the inhibitor and active site residue of trypsin is expected to be stronger than that of the amidine-based inhibitor. To confirm the above assumption, guanidine-containing Schiff base copper(II) and iron(III) chelates were synthesized. In addition, amidine- and guanidine-containing Schiff base zinc(II) chelates were synthesized, since zinc(II) ion is known to be one of the important elements found in metalloproteins or metalloenzymes.

This paper deals with both the syntheses of Schiff base metal chelates and the study their inhibitory activity against bovine $\beta$-trypsin with the final goal of discovering clinically useful chelate compounds.

\section{Results and Discussion}

Syntheses and Characterization 3-Formyl-4-hydroxyphenylguanidine hydrochloride (6), a key compound in this study, was prepared from 2-hydroxy-5-nitrobenzaldehyde (1) as shown in Chart 1 . The formyl group in compound $\mathbf{1}$ was protected with ethylene glycol in the presence of $p$-toluenesulfonic acid in benzene to give rise to the acetal (2). Amine compound $\mathbf{3}$ was obtained by catalytic hydrogenation of $\mathbf{2}$ in dioxane-EtOH. Compound 3 was reacted with the amidination reagent 1-[N, $N^{\prime}$-bis(Z)amidino]pyrazole, which was prepared according to the reported procedure ${ }^{26,27)}$ in THF to give 
4. Deprotection of the bis $(\mathrm{Z})$ compound $\mathbf{4}$ was carried out by catalytic hydrogenation over $10 \% \mathrm{Pd}-\mathrm{C}$ in $\mathrm{EtOH}-\mathrm{Et}_{2} \mathrm{O}$ to give $\mathbf{5}$, and then treated with $2 \mathrm{M} \mathrm{HCl}$ to give $\mathbf{6}$. Since compound $\mathbf{6}$ undergoes rapid decomposition when converted to the free base, the compound must be kept acidic during purification and storage. The structure of $\mathbf{6}$ was assigned on the basis of IR and NMR spectra and elemental analysis. The IR spectrum of $\mathbf{6}$ is shown by broad strong bands in the region of $3150-3400 \mathrm{~cm}^{-1}$ due to typical amine absorptions (NH stretching) and the strong band at $1657 \mathrm{~cm}^{-1}$ is assigned to $\mathrm{C}=\mathrm{N}$ streching. ${ }^{28)}$ The physical and spectral data of compounds $\mathbf{2}-\mathbf{6}$ are listed in Table 1.

Syntheses of the guanidine-containing Schiff base copper(II) $(7 \mathbf{a}-\mathbf{i})$ and zinc(II) chelates $(\mathbf{8} \mathbf{a}-\mathbf{i})$ were achieved by mixing equimolar amounts of $\mathbf{6}$, L-amino acids, and copper(II) or zinc(II) acetate, respectively. The corresponding iron(III) chelates $(\mathbf{9 a}-\mathbf{i})$ were obtained by adding
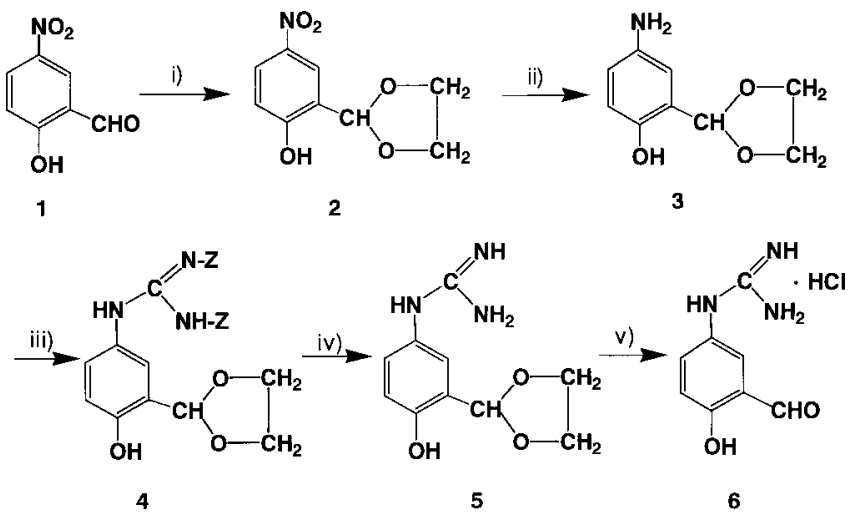

i) Ethylene glycol, $\rho-\mathrm{TsOH} \cdot \mathrm{H}_{2} \mathrm{O}$ in benzene

ii) $\mathrm{H}_{2}, 10 \% \mathrm{Pd}-\mathrm{C}$ in dioxane-EtOH $(5: 1)$

iii) 1 - $\left[N, N^{\prime}\right.$-bis(benzyloxycarbonyl)amidino]pyrazole in THF

iv) $\mathrm{H}_{2}, 10 \% \mathrm{Pd}-\mathrm{C}$ in $\mathrm{EtOH}-\mathrm{Et}_{2} \mathrm{O}(1: 1)$

v) $\mathrm{HCl}$ in $\mathrm{EtOH}$

Chart 1
iron(II) acetate to a solution of a stoichiometric amount of $\mathbf{6}$ and L-amino acids. The amidine-containing Schiff base zinc(II) chelates (10a-i) were prepared from 3-formyl-4hydroxybenzamidine hydrochloride, ${ }^{23)}$ L-amino acids, and zinc(II) acetate.

Structural formulae of the metal chelates (7-10) are shown in Fig. 1, and the physical and spectral data are summarized in Table 2. The structure of copper(II) and iron(III) chelates $(7,9)$ is readily assigned on the basis of their elemental analysis and spectral properties. In our previous studies of amidine-containing copper(II) (11) and iron(III) chelates (12), ${ }^{23,24)}$ formation of the Schiff base metal chelate was ascertained by the appearance of a marked absorption at $360-380 \mathrm{~nm}$ for copper(II) chelates and at $430-475 \mathrm{~nm}$ for iron(III) chelates, which can be attributed to a $\pi \rightarrow \pi^{*}$ transition originating mainly from the azomethine chromophore. The absorption spectra of $\mathbf{7}$ and $\mathbf{9}$ are consistent with those of $\mathbf{1 1}$ and $\mathbf{1 2}$, respectively. In the IR spectra, the copper(II) and iron(III) chelates $(\mathbf{7 b}, \mathbf{9 b})$ showed characteristic bands at $3100-3450 \mathrm{~cm}^{-1}, c a .1670 \mathrm{~cm}^{-1}, c a$. $1640 \mathrm{~cm}^{-1}, c a .1620 \mathrm{~cm}^{-1}$, and $c a .1300 \mathrm{~cm}^{-1}$. The broad band in the region of $3100-3450 \mathrm{~cm}^{-1}$ is due to $v\left(\mathrm{H}_{2} \mathrm{O}\right)$ and $v(\mathrm{NH})$. The band at $c a .1670 \mathrm{~cm}^{-1}$ is assigned to be $v(\mathrm{C}=\mathrm{N})$ of the guanidinium group. The bands at $c a$. $1640 \mathrm{~cm}^{-1}$ and $c a .1620 \mathrm{~cm}^{-1}$ are assigned to $v(\mathrm{C}=\mathrm{N})$ and $v\left(\mathrm{COO}^{-}\right)$, respectively, indicating coordination through imine nitrogen and carboxyl oxygen to the metal ion. ${ }^{29,30)}$ The phenolic $\mathrm{C}-\mathrm{O}$ vibration band in chelates appeared at $c a$. $1300 \mathrm{~cm}^{-1}$. This is evidence of the bonding of the metal ion with phenolic oxygen, since the phenolic $v(\mathrm{C}-\mathrm{O})$ in the free Schiff base is usually found near $1280 \mathrm{~cm}^{-1}$. $^{31)}$ In addition, elemental analysis of chelates indicated the ratio of metal to Schiff base ligand is $1: 1$ for copper(II) chelate and $1: 2$ for iron(III) chelate. From these observations, the coordination of copper(II) chelates was revealed to be a square planar geometry, and copper(II) ion coordinates to carboxyl oxygen, imine nitrogen, phenolic oxygen of Schiff base ligand, and a

Table 1. Physical and Spectral Data of Compounds 2 - 6

\begin{tabular}{|c|c|c|c|c|c|c|c|c|c|}
\hline \multirow{2}{*}{$\begin{array}{l}\text { Comp. } \\
\text { No. }\end{array}$} & \multirow{2}{*}{$\begin{array}{l}\mathrm{mp}(\mathrm{dec} .) \\
\left({ }^{\circ} \mathrm{C}\right)\end{array}$} & \multirow{2}{*}{$\begin{array}{l}\mathrm{IR}(\mathrm{KBr}) \\
v\left(\mathrm{~cm}^{-1}\right)\end{array}$} & \multicolumn{2}{|l|}{${ }^{1} \mathrm{H}-\mathrm{NMR}$} & \multirow{2}{*}{ Formula } & \multicolumn{4}{|c|}{ Analysis (\%) Calcd (Found) } \\
\hline & & & $\delta(\mathrm{ppm}), J(\mathrm{~Hz})$ & Solvent ${ }^{a}$ & & $\mathrm{C}$ & $\mathrm{H}$ & $\mathrm{N}$ & $\mathrm{Cl}$ \\
\hline 2 & $72-73$ & $\begin{array}{l}3248 \\
2894 \\
1594\end{array}$ & $\begin{array}{l}4.1-4.2(4 \mathrm{H}, \mathrm{m}), 6.00(1 \mathrm{H}, \mathrm{s}) \\
6.96(1 \mathrm{H}, \mathrm{d}, 8.8) \\
8.15(1 \mathrm{H}, \mathrm{dd}, 2.9,8.8) \\
8.21(1 \mathrm{H}, \mathrm{d}, 2.9), 8.59(1 \mathrm{H}, \mathrm{s})\end{array}$ & 1) & $\mathrm{C}_{9} \mathrm{H}_{9} \mathrm{NO}_{5}$ & $\begin{array}{r}51.19 \\
(51.18\end{array}$ & $\begin{array}{l}4.31 \\
4.37\end{array}$ & $\begin{array}{l}6.63 \\
6.62\end{array}$ & - ) \\
\hline 3 & $116-118$ & $\begin{array}{l}3329 \\
3290 \\
3200 \\
2904\end{array}$ & $\begin{array}{l}3.85(2 \mathrm{H}, \mathrm{m}), 3.98(2 \mathrm{H}, \mathrm{m}) \\
4.45(2 \mathrm{H}, \mathrm{s}), 5.84(1 \mathrm{H}, \mathrm{s}) \\
6.42(1 \mathrm{H}, \mathrm{dd}, 2.5,8.8) \\
6.52(1 \mathrm{H}, \mathrm{d}, 8.8) \\
6.62(1 \mathrm{H}, \mathrm{d}, 2.5), 8.52(1 \mathrm{H}, \mathrm{s})\end{array}$ & 2) & $\mathrm{C}_{9} \mathrm{H}_{11} \mathrm{NO}_{3}$ & $\begin{array}{r}59.66 \\
(59.71\end{array}$ & $\begin{array}{l}6.12 \\
6.20\end{array}$ & $\begin{array}{l}7.73 \\
7.73\end{array}$ & - \\
\hline 4 & $79-81$ & $\begin{array}{l}2900-3400 \\
1728 \\
1717 \\
1644\end{array}$ & $\begin{array}{l}4.0-4.1(4 \mathrm{H}, \mathrm{m}), 5.13(2 \mathrm{H}, \mathrm{s}) \\
5.22(2 \mathrm{H}, \mathrm{s}), 5.91(1 \mathrm{H}, \mathrm{s}) \\
6.83(1 \mathrm{H}, \mathrm{d}, 8.8), \\
7.2-7.4(12 \mathrm{H}, \mathrm{m}), 7.74(1 \mathrm{H}, \mathrm{s}) \\
10.07(1 \mathrm{H}, \mathrm{s}), 11.90(1 \mathrm{H}, \mathrm{s})\end{array}$ & 1) & $\mathrm{C}_{26} \mathrm{H}_{25} \mathrm{~N}_{3} \mathrm{O}_{7}$ & $\begin{array}{r}63.53 \\
(63.68\end{array}$ & $\begin{array}{l}5.13 \\
5.27\end{array}$ & $\begin{array}{l}8.56 \\
8.62\end{array}$ & - ) \\
\hline 5 & $(164-165)$ & $\begin{array}{l}2900-3400 \\
1670\end{array}$ & $\begin{array}{l}3.8-4.0(4 \mathrm{H}, \mathrm{m}), 5.90(1 \mathrm{H}, \mathrm{s}) \\
6.64(2 \mathrm{H}, \mathrm{s}), 6.79(1 \mathrm{H}, \mathrm{s})\end{array}$ & 2) & $\mathrm{C}_{10} \mathrm{H}_{13} \mathrm{~N}_{3} \mathrm{O}_{3}$ & $\begin{array}{r}53.80 \\
(53.40\end{array}$ & $\begin{array}{l}5.87 \\
6.07\end{array}$ & $\begin{array}{l}18.83 \\
18.62\end{array}$ & - \\
\hline 6 & $200-202$ & $\begin{array}{l}3150-3400 \\
1657 \\
1629\end{array}$ & $\begin{array}{l}7.13(1 \mathrm{H}, \mathrm{d}, 8.8) \\
7.37(1 \mathrm{H}, \mathrm{dd}, 2.4,8.8) \\
7.44(5 \mathrm{H}, \mathrm{s}), 9.80(1 \mathrm{H}, \mathrm{s}) \\
10.27(1 \mathrm{H}, \mathrm{s}), 11.08(1 \mathrm{H}, \mathrm{s})\end{array}$ & 2) & $\mathrm{C}_{8} \mathrm{H}_{10} \mathrm{ClN}_{3} \mathrm{O}_{2}$ & $\begin{array}{r}44.56 \\
(44.67\end{array}$ & $\begin{array}{l}4.67 \\
4.83\end{array}$ & $\begin{array}{l}19.51 \\
19.77\end{array}$ & $\begin{array}{l}16.44 \\
16.28)\end{array}$ \\
\hline
\end{tabular}




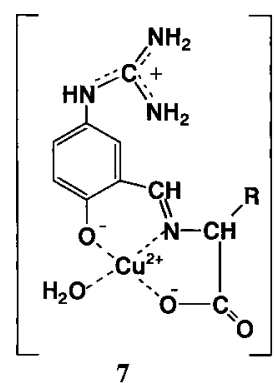

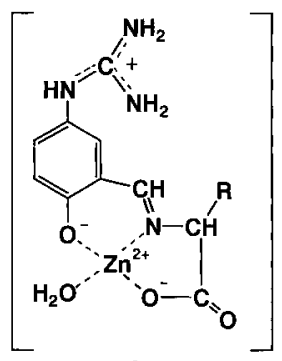

8

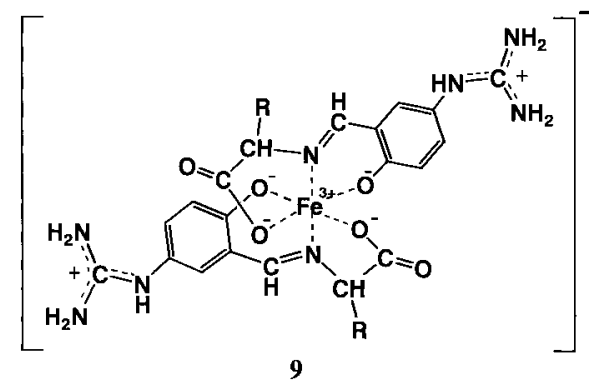

10

Fig. 1. Chemical Formulae of the Schiff Base Metal Chelates

Table 2. Physical and Spectral Data of Metal Chelates $\mathbf{7 b}-\mathbf{1 0 b}$

\begin{tabular}{|c|c|c|c|c|c|c|c|c|c|}
\hline & \multirow{2}{*}{ Compound } & \multirow{2}{*}{$\begin{array}{l}\mathrm{mp}(\mathrm{dec} .) \\
\left({ }^{\circ} \mathrm{C}\right)\end{array}$} & \multirow{2}{*}{$\begin{array}{l}\mathrm{IR}(\mathrm{KBr}) \\
v\left(\mathrm{~cm}^{-1}\right)\end{array}$} & \multirow{2}{*}{$\begin{array}{c}\text { Absorption } \\
\text { spectra }\left(\mathrm{H}_{2} \mathrm{O}\right) \\
\mathrm{nm}(\varepsilon)\end{array}$} & \multirow{2}{*}{ Formula } & \multicolumn{4}{|c|}{ Analysis (\%) Calcd (Found) } \\
\hline & & & & & & $\mathrm{C}$ & $\mathrm{H}$ & $\mathrm{N}$ & $\mathrm{Cl}$ \\
\hline $7 b$ & {$\left[\mathrm{Cu}\left(\right.\right.$ gua-sal-ala) $\left.\left(\mathrm{H}_{2} \mathrm{O}\right)\right] \mathrm{HCl}$} & $(224-226)$ & $\begin{array}{l}3100-3450 \\
1676,1636 \\
1617,1298\end{array}$ & $359(4750)$ & $\mathrm{C}_{11} \mathrm{H}_{15} \mathrm{ClCuN}_{4} \mathrm{O}_{4}$ & $\begin{array}{r}36.22 \\
(36.07\end{array}$ & $\begin{array}{l}4.09 \\
4.13\end{array}$ & $\begin{array}{l}15.30 \\
15.30\end{array}$ & $\begin{array}{l}9.95 \\
9.68)\end{array}$ \\
\hline $\mathbf{8 b}$ & {$\left[\mathrm{Zn}\right.$ (gua-sal-ala) $\left.\left(\mathrm{H}_{2} \mathrm{O}\right)\right] 0.5 \mathrm{H}_{2} \mathrm{O} \cdot \mathrm{HCl}$} & $(279-281)$ & $\begin{array}{l}3100-3450 \\
1670,1637 \\
1610,1292\end{array}$ & $354(4710)$ & $\mathrm{C}_{11} \mathrm{H}_{16} \mathrm{ClN}_{4} \mathrm{O}_{4.5} \mathrm{Zn}$ & $\begin{array}{r}35.21 \\
(35.03\end{array}$ & $\begin{array}{l}4.19 \\
4.28\end{array}$ & $\begin{array}{l}14.57 \\
14.86\end{array}$ & $\begin{array}{l}8.98 \\
9.40)\end{array}$ \\
\hline $9 b$ & $\mathrm{~K}\left[\mathrm{Fe}(\text { gua-sal-ala })_{2}\right] 3 \mathrm{H}_{2} \mathrm{O}$ & $(190-191)$ & $\begin{array}{l}3100-3400 \\
1670,1629 \\
1300\end{array}$ & $476(3470)$ & $\mathrm{C}_{22} \mathrm{H}_{30} \mathrm{FeKN}_{8} \mathrm{O}_{9}$ & $\begin{array}{r}41.17 \\
(40.93\end{array}$ & $\begin{array}{l}4.71 \\
4.68\end{array}$ & $\begin{array}{l}17.15 \\
17.36\end{array}$ & - \\
\hline $10 \mathrm{~b}$ & {$\left[\mathrm{Zn}(\right.$ ami-sal-ala $\left.)\left(\mathrm{H}_{2} \mathrm{O}\right)\right] 0.5 \mathrm{H}_{2} \mathrm{O} \cdot \mathrm{HCl}$} & $(254-256)$ & $\begin{array}{l}3100-3400 \\
1670,1640 \\
1608,1300\end{array}$ & $341(5360)$ & $\mathrm{C}_{11} \mathrm{H}_{15} \mathrm{ClN}_{3} \mathrm{O}_{4.5} \mathrm{Zn}$ & $\begin{array}{r}36.49 \\
(36.69\end{array}$ & $\begin{array}{l}4.18 \\
4.31\end{array}$ & $\begin{array}{l}11.61 \\
11.61\end{array}$ & $\begin{array}{l}9.79 \\
9.38\end{array}$ \\
\hline
\end{tabular}

Abbreviations: (gua-sal-ala), m-guanidinosalicylidene-L-alaninato; (ami-sal-ala), m-amidinosalicylidene-L-alaninato.

$\mathrm{H}_{2} \mathrm{O}$ molecule as shown in Fig. $1 .^{23,32,33)}$ On the other hand, the $\mathrm{C}=\mathrm{N}$ stretching band of the iron(III) chelate $(\mathbf{9 b})$ is shifted to a higher-frequency region $\left(1629 \mathrm{~cm}^{-1}\right)$ than that $\left(1636 \mathrm{~cm}^{-1}\right)$ of $7 \mathbf{b}$, and the $v\left(\mathrm{COO}^{-}\right)$band of $9 \mathbf{b}$ is broadened by overlapping with $v(\mathrm{C}=\mathrm{N})$ stretching. This is typical behavior of the bis(salicylideneamino acidato)iron(III) chelates. ${ }^{24,30)}$ Thus the iron(III) ion was concluded to have octahedral coordination geometry with two Schiff base ligands, as shown in Fig. 1.24,30,34,35)

Schiff base zinc(II) chelates derived from salicylaldehyde and amino acid are considered to have a four-coordination structure on the basis of their spectral properties, though Xray diffraction data have not been available. The IR and absorption spectra of zinc(II) chelates $(\mathbf{8 b}, \mathbf{1 0 b})$ were very similar to those of [(salicylideneamino acidato $\left.)\left(\mathrm{H}_{2} \mathrm{O}\right)\right] \mathrm{zinc}(\mathrm{II})$ chelates. $^{36-38)}$ Furthermore, elemental analysis of $\mathbf{8 b}$ and 10b indicated the ratio of metal to Schiff base ligand is $1: 1$. These results indicate that zinc(II) ion is tetrahedrally coordinated by a Schiff base ligand and a $\mathrm{H}_{2} \mathrm{O}$ molecule.

Inhibition Constant $\left(K_{\mathfrak{i}}\right)$ of Chelates against Bovine $\beta$ -
Trypsin The inhibitory activity of the chelates (7-10) against bovine $\beta$-trypsin was determined according to the reported procedure, ${ }^{23,24)}$ and the $K_{\mathrm{i}}$ values are listed in Table 3 . The $K_{\mathrm{i}}$ values $\left(\mathrm{ca} .10^{-5} \mathrm{M}\right)$ of the guanidine-containing Schiff base copper(II) $(\mathbf{7 a}-\mathbf{i})$ and zinc(II) chelates $(\mathbf{8 a}-\mathbf{i})$ indicate strong inhibition. On the other hand, remarkable inhibitory activity was not observed for iron(III) chelates except for 9a and $9 \mathrm{~b}$.

From the result of crystal structures of the amidine-based Schiff base inhibitor-trypsin complexes, ${ }^{25)}$ we anticipated that the increase in chain length between the guanidinium nitrogens, which form an ion pair with carboxyl oxygens of Asp189 in trypsin, and metal ion in the inhibitors must result in tighter interaction with the catalytic site and S1 site of trypsin. Especially, the bond distance of metal-His 57 must be shorter than that of the amidine-based inhibitor, that is, the inhibitory activity of guanidine-based inhibitors must be higher than corresponding amidine-based inhibitors. Unexpectedly, the inhibition against bovine $\beta$-trypsin of guanidine-containing copper(II) $\quad(\mathbf{7 a}-\mathbf{i})$ and $\operatorname{zinc}($ II) $\quad(\mathbf{8 a}-\mathbf{i})$ 
Table 3. Inhibition Constants of Copper(II), Zinc(II), and Iron(III) Chelates for Trypsin-Catalyzed Hydrolysis of Benzoyl-L-arginine $p$-Nitroanilide at pH 8.0

\begin{tabular}{|c|c|c|c|c|c|c|c|c|}
\hline \multirow{2}{*}{ Amino acid } & \multicolumn{4}{|c|}{$\begin{array}{l}\text { Guanidine-containing chelates } \\
\qquad \mathrm{Zn}(\mathrm{II})\end{array}$} & \multicolumn{2}{|c|}{$\mathrm{Fe}(\mathrm{III})$} & \multicolumn{2}{|c|}{$\begin{array}{l}\text { Amidine-containing chelates } \\
\qquad \mathrm{Zn}(\mathrm{II})\end{array}$} \\
\hline & No. & $K_{\mathrm{i}}(\mathrm{M})$ & No. & $K_{\mathrm{i}}(\mathrm{M})$ & No. & $K_{\mathrm{i}}(\mathrm{M})$ & No. & $K_{\mathrm{i}}(\mathrm{M})$ \\
\hline Gly & $7 \mathbf{a}$ & $2.8 \times 10^{-5}$ & $8 \mathbf{a}$ & $9.5 \times 10^{-5}$ & $9 a$ & $7.8 \times 10^{-5}$ & $10 a$ & $7.1 \times 10^{-6}$ \\
\hline L-Ala & $7 b$ & $3.1 \times 10^{-5}$ & $8 b$ & $7.3 \times 10^{-5}$ & $9 b$ & $1.8 \times 10^{-4}$ & $10 \mathrm{~b}$ & $7.6 \times 10^{-6}$ \\
\hline L-Val & $7 c$ & $5.0 \times 10^{-5}$ & $8 c$ & $8.8 \times 10^{-5}$ & $9 c$ & $1.1 \times 10^{-3}$ & $10 \mathrm{c}$ & $7.5 \times 10^{-6}$ \\
\hline L-Leu & $7 d$ & $3.5 \times 10^{-5}$ & 8d & $7.3 \times 10^{-5}$ & 9d & $3.4 \times 10^{-3}$ & 10d & $4.4 \times 10^{-6}$ \\
\hline L-Ile & $7 e$ & $2.6 \times 10^{-5}$ & $8 e$ & $9.3 \times 10^{-5}$ & $9 e$ & $3.0 \times 10^{-3}$ & $10 \mathrm{e}$ & $9.8 \times 10^{-6}$ \\
\hline L-Phe & $7 f$ & $1.1 \times 10^{-5}$ & $8 f$ & $8.6 \times 10^{-5}$ & 9f & $2.5 \times 10^{-3}$ & $10 f$ & $6.0 \times 10^{-6}$ \\
\hline L-Met & $7 \mathrm{~g}$ & $1.1 \times 10^{-5}$ & $8 g$ & $7.8 \times 10^{-5}$ & $9 g$ & $1.1 \times 10^{-3}$ & $10 \mathrm{~g}$ & $2.4 \times 10^{-5}$ \\
\hline L-Ser & $7 \mathrm{~h}$ & $4.7 \times 10^{-5}$ & $8 \mathrm{~h}$ & $9.7 \times 10^{-5}$ & $9 h$ & $1.1 \times 10^{-3}$ & $10 \mathrm{~h}$ & $1.7 \times 10^{-5}$ \\
\hline L-Thr & $7 \mathbf{i}$ & $4.0 \times 10^{-5}$ & $8 \mathbf{i}$ & $8.8 \times 10^{-5}$ & $9 \mathbf{i}$ & $1.1 \times 10^{-3}$ & $10 \mathrm{i}$ & $1.8 \times 10^{-5}$ \\
\hline
\end{tabular}

chelates was less than that of the corresponding amidinecontaining copper(II) $(\mathbf{1 1} \mathbf{a}-\mathbf{h})$ and zinc(II) chelates $(\mathbf{1 0 a}-$ i). This result suggests that the conformation of the active site of trypsin is a better fit for the amidine-based inhibitor than the guanidine-based inhibitor. Previous X-ray crystallographic studies indicated that the cationic guanidinium group formed salt bridge interactions with the carboxylate group of Asp189 in trypsin. ${ }^{17,18)}$ Thus a difference in the $\mathrm{p} K_{\mathrm{a}}$ value between the amidinium group and guanidinium group is the most important reason why the inhibitory activity does not increase with guanidine-based inhibitors. The reported $\mathrm{p} K_{\mathrm{a}}$ values for $p$-hydroxyphenylguanidinium ion and $p$-hydroxybenzamidinium ion are 9.05 and 12.69 , respectively. ${ }^{39,40)}$

In the iron(III) chelates, the $K_{\mathrm{i}}$ values of $\mathbf{9 a}$ and $\mathbf{9 b}$ derived from Gly or Ala were comparable to those of the copper(II) and zinc(II) chelates, although the inhibitory activity of $9 \mathbf{c}-$ $\mathbf{i}$ was very weak. At a higher concentration of $9 \mathbf{c}-\mathbf{i}$, competitive inhibition with $K_{\mathrm{i}}$ values of $c a .10^{-3} \mathrm{M}$, which is comparable to that for the binding of an aromatic compound to trypsin, was found. ${ }^{41)}$ In the model fitting of trypsin with $\mathbf{9 b}$, it was simulated that one of the Schiff base ligands would orient closely to the catalytic triad (His57, Asp102, Ser195) in such a manner that the guanidinium nitrogens of $\mathbf{9 b}$ form an ion pair with carboxyl oxygens of Asp189. Probably, octahedrally coordinated iron(III) chelates derived from amino acids (which have bulky side chains on the $\alpha$-carbon) such as Val, Leu, Ile, and Phe could not be included in the active site of trypsin due to unfavorable interactions with the active site residues. This is supported by the results of crystal structures of bis( $m$-amidinosalicylidene-L-alaninato)iron(III) (12b) and bis( $p$-amidinosalicylidene-L-alaninato)iron(III) (13b) bound to bovine trypsin. ${ }^{25}$ The refined structure of the trypsin-12b complex showed that inhibitor $\mathbf{1 2 b}$ did not bind to the trypsin, whereas inhibitor $\mathbf{1 3 b}$ was bound. In the case of the trypsin-12b complex, the iron(III) ion was replaced by magnesium ion which was present in the mother liquor, and one of the Schiff base ligands was replaced by solvent molecules to avoid unfavorable interactions with the active site residues.

The $K_{\mathrm{i}}$ values of guanidine- or amidine-containing Schiff base zinc(II) chelates $(\mathbf{8 a}-\mathbf{i}, \mathbf{1 0 a}-\mathbf{i})$ were somewhat larger than those of the corresponding copper(II) chelates $(\mathbf{7 a}-\mathbf{i})$ and $(11 \mathbf{a}-\mathbf{i}){ }^{23)}$ respectively (Table 3$)$. This observation implies that the coordination geometry of copper(II) ion is a better fit for the active site of trypsin than that of zinc(II) ion.
Further details of structural requirements for trypsin-inhibitor complex using the X-ray diffraction method will be described in a future paper.

In this study, the design of guanidine-based inhibitors with higher inhibitory activity than amidine-based inhibitors against bovine $\beta$-trypsin was not successful, although this approach will hopefully lead to the final goal of discovering clinically useful chelate compounds that inhibit trypsin-like enzymes.

\section{Experimental}

Materials 2-Hydroxy-5-nitrobenzaldehyde and iron(II) acetate were purchased from Aldrich Chemical Co., Ltd. Bovine $\beta$-trypsin (EC 3.4.21.4) was purchased from Worthington Biochemical Corp. (twice crystallized).

Instruments Melting points were measured on a Yanagimoto micro melting point apparatus. ${ }^{1} \mathrm{H}-\mathrm{NMR}$ spectra were recorded on a JNM-FX-400 spectrometer (JEOL). IR and absorption spectra were recorded on a FT/IR VALOR-III spectrometer (JASCO) and a U-2000 spectrophotometer (Hitachi), respectively.

Synthesis of 2-(1,4-Dioxa-5-cyclopentyl)-4-nitrophenol (2) A solution of 2-hydroxy-5-nitrobenzaldehyde (1) $(8.3 \mathrm{~g}, 49.7 \mathrm{mmol})$, ethylene glycol $(15.5 \mathrm{~g}, 250 \mathrm{mmol})$, and $p$-toluenesulfonic acid $(0.2 \mathrm{~g}, 1.1 \mathrm{mmol})$ in benzene $(400 \mathrm{ml})$ was refluxed for $4 \mathrm{~h}$ using the distilling receiver for water. The solution was transferred to a separatory funnel and the benzene layer was separated, washed with water and saturated $\mathrm{NaCl}$ solution, dried over anhydrous $\mathrm{Na}_{2} \mathrm{SO}_{4}$, and evaporated to dryness in vacuo. The residue was purified by recrystallization from benzene to give $\mathbf{2}(7.8 \mathrm{~g}$, yield $74 \%)$ as a colorless crystalline powder. Physical properties and spectral data are given in Table 1.

4-Amino-2-(1,4-dioxa-5-cyclopentyl)phenol (3) Palladium-activated carbon $(\mathrm{Pd} 10 \%)(200 \mathrm{mg})$ was added to a solution of $2(2.1 \mathrm{~g}, 9.9 \mathrm{mmol})$ in dioxane-EtOH $(5: 1)(300 \mathrm{ml})$, and the mixture was vigorously stirred for $1 \mathrm{~h}$ under an atmosphere of hydrogen at room temperature. The catalyst was filtered off, and the filtrate was evaporated to dryness in vacuo. The residue was purified by recrystallization from EtOH-hexane to give 3 (1.6 g, yield $89 \%)$ as pale brown needles. Physical properties and spectral data are given in Table 1.

4-[ $N^{\prime}, N^{\prime \prime}$-Bis(benzyloxycarbonyl)guanidino]-2-(1,4-dioxa-5-cyclopentyl)phenol (4) A solution of $\mathbf{3}(0.9 \mathrm{~g}, 5.0 \mathrm{mmol})$ and $1-\left[N, N^{\prime}-\right.$ bis(Z)amidino]pyrazole $(1.7 \mathrm{~g}, 5.0 \mathrm{mmol})$ in anhydrous THF $(1.0 \mathrm{ml})$ was stirred for $1 \mathrm{~h}$ at room temperature. The reaction mixture was concentrated in vacuo. The residue was purified by silica gel column chromatography. The eluate [benzene-ethyl acetate $(6: 1)$ ] was evaporated to dryness in vacuo and the solid residue was recrystallized from benzene-hexane to give $4(2.2 \mathrm{~g}$, yield $90 \%)$ as pale yellow prisms. Physical properties and spectral data are given in Table 1.

2-(1,4-Dioxa-5-cyclopentyl)-4-guanidinophenol (5) A solution of 4 $(2.0 \mathrm{~g}, 4.1 \mathrm{mmol})$ in $\mathrm{EtOH}_{-} \mathrm{Et}_{2} \mathrm{O}(1: 1)(250 \mathrm{ml})$ containing $10 \% \mathrm{Pd}-\mathrm{C}$ $(100 \mathrm{mg})$ was vigorously stirred for $1 \mathrm{~h}$ under an atmosphere of hydrogen at room temperature. The catalyst was filtered off, and the filtrate was evaporated to dryness in vacuo. The solid residue was recrystallized from $\mathrm{MeOH}-\mathrm{Et}_{2} \mathrm{O}$ to give $\mathbf{5}(0.8 \mathrm{~g}$, yield $87 \%)$ as a pale brown crystalline powder. 
Physical properties and spectral data are given in Table 1.

3-Formyl-4-hydroxyphenylguanidine Hydrochloride (6) To a solution of $5(1.12 \mathrm{~g}, 5.0 \mathrm{mmol})$ in EtOH $(5 \mathrm{ml})$ was added $2 \mathrm{M} \mathrm{HCl}(5 \mathrm{ml})$, and the precipitate was collected. Recrystallization from $\mathrm{EtOH}-\mathrm{Et}_{2} \mathrm{O}$ give a pale yellow crystalline powder $(0.77 \mathrm{~g}$, yield $71 \%)$. Physical properties and spectral data are given in Table 1.

m-Guanidinosalicylidene-L-alaninato(aqua)copper(II) Hydrochloride (7b) Synthesis was carried out following the procedure reported for $\mathrm{m}$ amidinosalicylidene-L-alaninato(aqua)copper(II). ${ }^{23)}$ To a solution of 6 $(0.22 \mathrm{~g}, 1.0 \mathrm{mmol})$ and L-alanine $(0.09 \mathrm{~g}, 1.0 \mathrm{mmol})$ in water $(2 \mathrm{ml})$ was added a solution of copper(II) acetate monohydrate $(0.2 \mathrm{~g}, 1.0 \mathrm{mmol})$ in water $(2 \mathrm{ml})$ and the mixture was stirred for $3 \mathrm{~h}$ at $50^{\circ} \mathrm{C}$. The reaction mixture was concentrated and subjected to Sephadex LH-20 column chromatography using $\mathrm{MeOH}$. The eluate was evaporated to dryness in vacuo, and the solid residue was recrystallized from $\mathrm{H}_{2} \mathrm{O}-\mathrm{EtOH}$ to give $7 \mathbf{b}(0.30 \mathrm{~g}$, yield $84 \%$ ) as a green crystalline powder. Physical properties and spectral data are given in Table 2 .

m-Guanidinosalicylidene-L-alaninato(aqua)zinc(II) Hemihydrate Hydrochloride (8b) Synthesis was carried out by the same procedure reported for ( $N$-salicylidene amino acidato)zinc(II) complexes. ${ }^{36,38)}$ Equimolar amounts of 6, L-alanine, and zinc(II) acetate dihydrate $(1.0 \mathrm{mmol})$ were dissolved in $\mathrm{H}_{2} \mathrm{O}-\mathrm{MeOH}(15 \mathrm{ml})$, and the mixture was stirred for $8 \mathrm{~h}$ at room temperature. The reacted precipitate was collected by filtration. Complex was purified by recrystallization from $\mathrm{H}_{2} \mathrm{O}-\mathrm{EtOH}$ and dried under a vacuum. A white powder was obtained $(0.2 \mathrm{~g}$, yield $53 \%)$. Physical properties and spectral data are given in Table 2.

Potassium Bis( $m$-guanidinosalicylidene-L-alaninato)iron(III) Trihydrate (9b) Synthesis was carried out following the procedure reported for potassium bis $\left(m\right.$-amidinosalicylidene-L-alaninato)iron(III) $(\mathbf{1 2 b}){ }^{24)} \mathrm{A}$ mixture of $6(0.43 \mathrm{~g}, 2.0 \mathrm{mmol})$, L-alanine $(0.18 \mathrm{~g}, 2.0 \mathrm{mmol})$, and potassium hydroxide $(0.23 \mathrm{~g}, 4.1 \mathrm{mmol})$ in $\mathrm{H}_{2} \mathrm{O}$-EtOH $(15 \mathrm{ml})$ was stirred for several minutes at room temperature. To the reaction mixture, an ethanolic solution of iron(II) acetate enneahydrate $(0.17 \mathrm{~g}, 1.0 \mathrm{mmol})$ was added over about $15 \mathrm{~min}$. The solution was stirred for $8 \mathrm{~h}$ at room temperature and evaporated to dryness. The residue was subjected to a column chromatography on Sephadex LH-20 (MeOH). The eluate was concentrated until precipitation of the product occurred. The precipitate was collected by filtration, washed with $\mathrm{EtOH}$ and $\mathrm{Et}_{2} \mathrm{O}$, and dried under a vacuum. A reddish brown powder was obtained $(0.4 \mathrm{~g}$, yield $31 \%)$. Physical properties and spectral data are given in Table 2.

m-Amidinosalicylidene-L-alaninato(aqua)zinc(II) Hemihydrate Hydrochloride (10b) Equimolar amounts of 3-formyl-4-hydroxybenzamidine hydrochloride, L-alanine, and zinc(II) acetate dihydrate $(1.0 \mathrm{mmol})$ were dissolved in $\mathrm{H}_{2} \mathrm{O}-\mathrm{MeOH}(15 \mathrm{ml})$ and then mixture was stirred for $8 \mathrm{~h}$ at room temperature. The complex was purified by recrystallization from $\mathrm{H}_{2} \mathrm{O}-\mathrm{MeOH}$ and dried under a vacuum. A white powder was obtained $(0.2 \mathrm{~g}$, yield $55 \%)$.

Determination of Inhibitory Activity $\left(\boldsymbol{K}_{\mathrm{i}}\right)$ of Chelates Enzyme activity was determined in $50 \mathrm{~mm}$ Tris- $\mathrm{HCl}$ buffer containing $20 \mathrm{~mm} \mathrm{CaCl}_{2}(\mathrm{pH}$ 8 ) using benzoyl-L-arginine $p$-nitroanilide (BAPA) as a substrate. Determination of $K_{\mathrm{i}}$ values was carried out as follows: Concentrations of the inhibitor and trypsin used in the kinetic analysis were $10^{-4}-10^{-5} \mathrm{M}$ and $10^{-6} \mathrm{M}$, respectively. Hydrolytic rates in the presence of chelate were determined and the $K_{\mathrm{i}}$ values were calculated according to the method of Dixon ${ }^{42)}$ using a linear regression program.

Acknowledgments This work was supported in part by the Akiyama Foundation and the High Technology Research Program from the Ministry of Education, Culture, Sports, Science, and Technology of Japan.

\section{References}

1) Mares-Guia M., Shaw E., J. Biol. Chem., 240, 1579-1585 (1965).

2) Mares-Guia M., Shaw E., Cohen W., J. Biol. Chem., 242, 5777-5781 (1967).

3) Mares-Guia M., Shaw E., J. Biol. Chem., 242, 5782-5788 (1967).

4) Tamura Y., Hirado M., Okamura K., Minato Y., Fujii S., Biochim. Biophys. Acta, 484, 417-422 (1977).

5) Tidwell R. R., Geratz J. D., J. Med. Chem., 21, 613-623 (1978).
6) Tidwell R. R., Geratz J. D., Dubovi E. J., J. Med. Chem., 26, 294-298 (1983).

7) Nochi S., Shimomura N., Hattori T., Sato T., Miyake Y., Tanizawa K., Chem. Pharm. Bull., 37, 2855-2857 (1989).

8) Matsumoto O., Masuda H., Taga T., Kuroda Y., Machida K., Chem. Pharm. Bull., 38, 2015-2017 (1990).

9) Senokuchi K., Nakai H., Nakayama Y., Odagaki Y., Sasaki K., Kato M., Maruyama T., Miyazaki T., Ito H., Kamiyasu K., Kim S., Kawamura M., Hamanaka N., J. Med. Chem., 38, 2521-2523 (1995).

10) Odagaki Y., Nakai H., Senokuchi K., Kawamura M., Hamanaka N., Nakamura M., Tomoo K., Ishida T., Biochemistry, 34, 12849-12853 (1995).

11) Stürzebecher J., Prasa D., Wikström P., Vieweg H., J. Enzyme Inhib., 9, 87-99 (1995).

12) Stürzebecher J., Prasa D., Hauptmann J., Vieweg H., Wikström P., J. Med. Chem., 40, 3091-3099 (1997).

13) Bartunik H. D., Summers L. J., Bartsch H. H., J. Mol. Biol., 210, 813-828 (1989).

14) Renatus M., Bode W., Huber R., Stürzebecher J., Stubbs M. T., J. Med. Chem., 41, 5445-5456 (1998).

15) Marquart M., Walter J., Deisenhofer J., Bode W., Huber R., Acta Crystallogr. Sect. B, 39, 480-490 (1983).

16) Katz B. A., Clark J. M., Finer-Moore J. S., Jenkins T. E., Johnson C. R., Ross M. J., Luong C., Moore W. R., Stroud R. M., Nature (London), 391, 608-612 (1998).

17) Mangel W. F., Singer P. T., Cyr D. M., Umland T. C., Toledo D. L., Stroud R. M., Pflugrath J. W., Sweet R. M., Biochemistry, 29, 83518357 (1990).

18) Matsumoto O., Taga T., Matsushima M., Higashi T., Machida K., Chem. Pharm. Bull., 38, 2253-2255 (1990).

19) Turk D., Sturzebecher J., Bode W., FEBS Lett., 287, 133-138 (1991).

20) Glusker J. P., Adv. Protein Chem., 42, 1-76 (1991).

21) Brinen L. S., Willett W. S., Craik C. S., Fletterick R. J., Biochemistry, 35, 5999-6009 (1996).

22) Katz B. A., Luong C., J. Mol. Biol., 292, 669—684 (1999).

23) Toyota E., Chinen C., Sekizaki H., Itoh K., Tanizawa K., Chem. Pharm. Bull., 44, 1104-1106 (1996).

24) Toyota E., Miyazaki H., Itoh K., Sekizaki H., Tanizawa K., Chem. Pharm. Bull., 47, 116-119 (1999).

25) Toyota E., Ng K. K. S., Sekizaki H., Itoh K., Tanizawa K., James M. N. G., J. Mol. Biol., 305, 471-479 (2001).

26) Bernatowicz M. S., Wu Y., Matsueda G. R., J. Org. Chem., 57, 24972502 (1992).

27) Bernatowicz M. S., Wu Y., Matsueda G. R., Tetrahedron Lett., 34, 3389-3392 (1993).

28) Goto T., Nakanishi K., Ohashi M., Bull. Chem. Soc. Jpn., 30, 723725 (1957).

29) Heinert D., Martell A. E., J. Am. Chem. Soc., 84, 3257-3263 (1962).

30) Burrows R. C., Bailar J. C., Jr., J. Am. Chem. Soc., 88, 4150-4155 (1966).

31) Kovacic J. E., Spectrochim. Acta, Part A, 23, 183-187 (1967).

32) Nakahara A., Bull. Chem. Soc. Jpn., 32, 1195-1199 (1959).

33) Ueki T., Ashida T., Sasada Y., Kakudo M., Acta Crystallogr., 22, 870 -878 (1967).

34) Hämäläinen R., Turpeinen U., Acta Chem. Scand., 43, 15-18 (1989).

35) Bowden F. L., Carpenter R. P., Parish R. V., Pollock R. D., Inorg. Chim. Acta, 23, 35-36 (1977).

36) O'Connor M. J., Ernst R. E., Schoenborn J. E., Holm R. H., J. Am. Chem. Soc., 90, 1744-1752 (1968).

37) Leussing D. L., Bai K. S., Anal. Chem., 40, 575-581 (1968).

38) Casella L., Gullotti M., J. Am. Chem. Soc., 103, 6338-6347 (1981).

39) Koike H., Nippon Kagaku Zasshi, 83, 917-923 (1962).

40) Rogana E., Nelson D. L., Leite L. F. F., Mares-Guia M., J. Chem. Res. (S), 1985, 286-287.

41) Inagami T., "Proteins. Structure and Function," Vol. 1, ed. by Funatsu M., Hiromi K., Murachi T., Narita K., Kodansha, Tokyo, 1971, pp. 183.

42) Dixon M., Biochem. J., 55, 170-171 (1953). 